\title{
Chayamaritia vietnamensis (Gesneriaceae), a new species from Son La Province, northern Vietnam
}

\author{
Zi-Bing Xin ${ }^{1,2,6,}$, Long-Fei Fu' ${ }^{1,2,6,}{ }^{*}$, Stephen Maciejewski ${ }^{2,3}$, \\ Zhang-Jie Huang ${ }^{1,2}$, Truong Van Do ${ }^{4,5}$, Fang Wen ${ }^{1,2,6}$
}

I Guangxi Key Laboratory of Plant Conservation and Restoration Ecology in Karst Terrain, Guangxi Institute of Botany, Guangxi Zhuang Autonomous Region and Chinese Academy of Sciences, CN-541006, Guilin, China 2 Gesneriad Conservation Center of China (GCCC), National Gesneriaceae Germplasm Bank of GXIB, Guilin Botanical Garden, Guangxi Zhuang Autonomous Region and Chinese Academy of Sciences, CN541006 Guilin, China 3 The Gesneriad Society, 2030 Fitzwater Street, Philadelphia, PA, 19146-1333, USA 4 Vietnam National Museum of Nature, Vietnam Academy of Science \& Technology, 18 Hoang Quoc Viet, Hanoi, Vietnam 5 Graduate University of Science and Technology, Vietnam Academy of Science \& Technology, 18 Hoang Quoc Viet, Hanoi, Vietnam 6 Gesneriad Committee, China Wild Plant Conservation Association, CN-541006, Guilin, China

Corresponding authors: Fang Wen (wenfang760608@139.com); Truong Van Do (dovantruong_bttn@yahoo.com)

Academic editor: M. Moeller | Received 20 January 2021 | Accepted 20 April 2021 | Published 12 May 2021

Citation: Xin Z-B, Fu L-F, Maciejewski S, Huang Z-J, Do TV, Wen F (2021) Chayamaritia vietnamensis (Gesneriaceae), a new species from Son La Province, northern Vietnam. PhytoKeys 177: 43-53. https://doi. org/10.3897/phytokeys.177.63401

\begin{abstract}
Chayamaritia vietnamensis, a new species from Son La Province, northern Vietnam, is described and illustrated. The phylogenetic study revealed that the new species is most closely related to C. banksiae and C. smitinandii. The morphological comparison suggests it as the third new species of Chayamaritia and distinguished from C. banksiae and C. smitinandii by a combination of morphological characters of leaf blades, bracts, calyx and corolla, especially its peltate leaf blades. This species is provisionally assessed as endangered (EN B1ab(iii), B2ab(iii)) using IUCN Categories and Criteria. Information on ecology, phenology and an identification key for the known Chayamaritia species are also provided.
\end{abstract}

\section{Keywords}

Cliff-dwelling, Flora of Vietnam, new taxon, taxonomy

\footnotetext{
* These authors contributed equally to this work as co-first authors.
}

Copyright Zi-Bing Xin et al. This is an open access article distributed under the terms of the Creative Commons Attribution License (CC BY 4.0), which permits unrestricted use, distribution, and reproduction in any medium, provided the original author and source are credited. 


\section{Introduction}

The genus Chayamaritia D.J.Middleton \& Mich.Möller (Gesneriaceae) was originally established and described, based on molecular and morphological data (Middleton et al. 2015). The genus Chayamaritia comprises two species and is hitherto known only in Laos and Thailand. A thickened rhizomatous prostrate stem, along with alternately arranged leaves and the imbricate sepals characterise the genus (Middleton et al. 2015). The type species, Chayamaritia smitinandii (B.L.Burtt) D.J.Middleton, was initially placed in the genus Chirita Buch.-Ham. (Burtt, 2001), then transferred to the genus Henckelia Spreng. (Weber et al. 2011) and eventually separated as a new genus in 2015, together with the newly-described species, Chayamaritia banksiae D.J.Middleton (Middleton et al. 2015). Chayamaritia banksiae and C. smitinandii are endemic to Laos and Thailand, respectively (Middleton et al. 2015).

During a joint Sino-Vietnamese botanical survey for plant biodiversity in northern Vietnam in late October 2019, we collected an unknown Gesneriaceae plant. In the Xuan Nha Nature Reserve, Moc Chau District, Son La Province, northern Vietnam, we discovered this plant that looked like a Chayamaritia species. Detailed comparison of these specimens with the type specimens and protologues of known Chayamaritia species showed that these specimens neither fitted the existing protologues nor conformed to the type specimens of these species. Although, the leaf indumentum and inflorescence of the unknown plant was most similar to those of C. banksiae and C. smitinandii, it could be easily distinguished from the latter two by the combination of several morphological characters of the leaf blades, bracts, calyx and corolla, especially its peltate leaf blade. Thus, we confirmed that it represented a new species of Chayamaritia, which is the first Chayamaritia species from Vietnam. The description, illustration, information on ecology, phenology and provisional conservation assessment using IUCN (2019) of the proposed new species are provided. Furthermore, an identification key to the known Chayamaritia species is given.

\section{Material and methods}

\section{Plant material}

Herbarium materials were studied from the following herbaria: E, IBK, US and VNMN (herbarium acronyms according to Index Herbariorum; Thiers 2019). The macromorphological features were observed, based on the specimen sheets and notes in both the field and the conservation nursery at the Gesneriad Conservation Center of China and the National Gesneriaceae Germplasm Bank at GXIB. Micromorphological features were analysed and photographed using an optical microscope (Stemi DV4, LEICA S8 AP0, Jena, Germany).

These morphological characters of newly-proposed species were compared with those of the two known Chayamaritia species from protologues, type specimens and living plants. The description of the new species followed the terminology used by Harris and Harris (2001) and Wang et al. (1998). Assessment of the conservation status of the new species was according to Categories and Criteria of the IUCN (2019). 


\section{DNA extraction, PCR amplification and sequencing}

Leaves were dried using silica gel for DNA extraction (Chase and Hills 1991). Genomic DNA was extracted using the CTAB protocol (Doyle and Doyle 1987). To confirm the placement of this new species, we performed phylogenetic studies of DNA sequence data obtained from the nuclear ribosomal internal transcribed spacer (ITS) region and the plastid trnL-F intron spacer $(\operatorname{trn} L-F)$. Given the phylogenetic studies of Middleton et al. (2015), we sampled two species (three accessions) from Chayamaritia and the new species as ingroup and ten species from all closely related and morphologically similar genera, including Allostigma (one species), Deinostigma (two species), Loxostigma (two species), Petrocosmea (two species), Pseudochirita (two varieties) and Primulina (two species) as outgroup (Middleton et al. 2015). DNA extraction, PCR amplification and sequencing were performed following Wei et al. (2013). The species name, voucher specimens and GenBank accession numbers of DNA sequences used in this study are listed in Table 1 .

\section{Phylogenetic analysis}

The sequence data were edited and assembled using Lasergene Navigator 7.1 (DNAstar, Madison, Wisconsin, USA). Two datasets (ITS and trnL-F) were aligned independently using MAFFT version 7.0 (Katoh and Standley 2013) with default settings. The two best-supported tree topologies from Maximum Likelihood (ML) analyses of ITS and $\operatorname{trnL-F}$ were compared visually for topological incongruences. As there were no hard incongruences (Nishii et al. 2015), phylogenies were reconstructed, based on the combined dataset using ML and Bayesian Inference (BI). BI was performed using MRBAYES v.3.2.7 (Ronquist et al. 2012). Best-fitting models for the $\mathrm{BI}$ analysis were obtained independently for each gene region using MODELTEST v.3.7 (Posada and Buckley 2004). GTR+G and GTR+I were the best-fitting models for ITS and trnL-F, respectively. One cold and three incrementally heated Markov Chain Monte Carlo (MCMC) chains were run for five million generations and trees were sampled every 1,000 generations (5,000 trees sampled in total). The first 1250 trees (25\%) were discarded as burn-in prior to calculating the BI consensus trees and posterior probabilities (PP) (See Suppl. material 1: $\log$ file). The ML analyses were performed in RAxML using raxmlGUI (Silvestro and Michalak 2012), with GTRGAMMA setting and 1,000 bootstrap replicates.

\section{Results}

The combined ITS and trnL-F matrix was 1,477 characters long (700 for ITS and 777 for $\operatorname{trn} L-F)$. Of the 378 variable characters, 155 (56.97\%) were parsimony-informative. ML and BI analyses resulted in the same tree topology indicating the undescribed species as sister to the two known Chayamaritia species $(\mathrm{BS}=97 \%$, $\mathrm{PP}=1)$, i.e. C. banksiae and C. smitinandii (Fig. 1). 
Table I. Species names, voucher specimens, and GenBank accession numbers of DNA sequences used in this study.

\begin{tabular}{|c|c|c|c|c|c|}
\hline Species name & Voucher number & Herbarium & Origin & ITS & trnL-F \\
\hline Allostigma guangxiense W.T.Wang & $\begin{array}{l}\text { M. Möller and Y.G. Wei } \\
\text { MMO 05-755 }\end{array}$ & E, IBK & $\begin{array}{l}\text { China, Guangxi, } \\
\text { Longzhou county }\end{array}$ & HQ632977 & HQ632880 \\
\hline $\begin{array}{l}\text { Deinostigma cicatricosa } \\
\text { (W.T.Wang) D.J.Middleton \& } \\
\text { Mich.Möller }\end{array}$ & W. B. Xu s.n. [XWB] & IBK & $\begin{array}{l}\text { China, unknown } \\
\text { locality }\end{array}$ & JX506925 & JX506817 \\
\hline $\begin{array}{l}\text { Deinostigma cyrtocarpa (D.Fang \& } \\
\text { L.Zeng) Mich.Möller \& } \\
\text { H.J.Atkins }\end{array}$ & $\begin{array}{l}\text { M. Möller and Y.G. Wei } \\
\text { MMO 06-908 }\end{array}$ & E, IBK & $\begin{array}{l}\text { China, Guangxi, } \mathrm{He} \\
\text { Zhou city }\end{array}$ & KU990889 & KU990885 \\
\hline $\begin{array}{l}\text { Pseudochirita guangxiensis } \\
\text { (S.Z.Huang) W.T.Wang }\end{array}$ & $\begin{array}{l}\text { M. Möller and Y.G. Wei } \\
\text { MMO 06-798 }\end{array}$ & E, IBK & $\begin{array}{l}\text { China, Guangxi, } \\
\text { Mashan county }\end{array}$ & HQ633003 & HQ632908 \\
\hline $\begin{array}{l}\text { Pseudochirita guangxiensis } \\
\text { (S.Z.Huang) W.T.Wang var. } \\
\text { glauca Y.G.Wei \& Yan Liu }\end{array}$ & $\begin{array}{l}\text { M. Möller and Y.G. Wei } \\
\text { MMO 05-751 }\end{array}$ & E, IBK & $\begin{array}{l}\text { China, Guangxi, Jingxi } \\
\text { county }\end{array}$ & HQ633004 & HQ632909 \\
\hline $\begin{array}{l}\text { Loxostigma glabrifolium D.Fang \& } \\
\text { K.Y.Pan }\end{array}$ & Y.G. Wei 709 & IBK & $\begin{array}{c}\text { China, Guangxi, Napo } \\
\text { county }\end{array}$ & HQ633006 & HQ632910 \\
\hline $\begin{array}{l}\text { Loxostigma griffithii (Wight) } \\
\text { C.B.Clarke }\end{array}$ & $\begin{array}{c}\text { Kew/Edinburgh } \\
\text { Kanchenjunga Expedition } \\
\text { (1989) } 940 \text { [Cult. RBGE } \\
\text { 19892473A] }\end{array}$ & $\mathrm{E}$ & Nepal, Yamphudin & FJ501338 & FJ501508 \\
\hline $\begin{array}{l}\text { Chayamaritia banksiae } \\
\text { D.J.Middleton }\end{array}$ & $\begin{array}{c}\text { D.J. Middleton } 5220 \text { and M. } \\
\text { Newman et al. LAO1428 }\end{array}$ & $\mathrm{E}$ & $\begin{array}{l}\text { Laos, Khammouan, } \\
\text { Nakai Nam Theun }\end{array}$ & KP325426 & KP325433 \\
\hline $\begin{array}{l}\text { Chayamaritia smitinandii } \\
\text { (B.L.Burtt) D.J.Middleton \& } \\
\text { Mich.Möller }\end{array}$ & D.J. Middleton et al. 5632 & $\mathrm{E}$ & $\begin{array}{l}\text { Thailand, Nakhon } \\
\text { Nayok, Khao Yai NP }\end{array}$ & KP325424 & KP325431 \\
\hline $\begin{array}{l}\text { Chayamaritia smitinandii } \\
\text { (B.L.Burtt) D.J.Middleton \& } \\
\text { Mich.Möller }\end{array}$ & D.J. Middleton et al. 5652 & $\mathrm{E}$ & $\begin{array}{l}\text { Thailand, Nakhon } \\
\text { Nayok, Khao Yai NP }\end{array}$ & KP325425 & KP325432 \\
\hline $\begin{array}{l}\text { Chayamaritia vietnamensis F.Wen, } \\
\text { T.V.Do, Z.B.Xin \& S.Maciej }\end{array}$ & $\begin{array}{c}\text { F. Wen, T.V. Do, Z.B. Xin \& } \\
\text { S. Maciejewski, VMN- } \\
\text { CN1214 }\end{array}$ & $\begin{array}{c}\text { IBK, } \\
\text { VNMN }\end{array}$ & $\begin{array}{c}\text { Vietnam, Son La, Moc } \\
\text { Chau }\end{array}$ & MW458944* & MW458945* \\
\hline Petrocosmea kerrii Craib & $\begin{array}{c}\text { Voucher from Cult. RBGE } \\
19715592\end{array}$ & $\mathrm{E}$ & unknown origin & FJ501334 & FJ501502 \\
\hline Petrocosmea nervosa Craib & $\begin{array}{c}\text { Smithsonian Institute 78-057 } \\
\text { [Cult. RBGE 19933232] }\end{array}$ & E, US & China, N Yunnan & FJ501335 & AJ492299 \\
\hline Primulina tabacum Hance & $\begin{array}{l}\text { Q.J. Xie and C.X. Ye s.n. } \\
\text { [Cult. RBGE 19951540] }\end{array}$ & $\mathrm{E}$ & $\begin{array}{c}\text { E China, Guangdong, } \\
\text { Lian Rive }\end{array}$ & FJ501352 & AJ492300 \\
\hline $\begin{array}{l}\text { Primulina gemella (D.Wood) Yin } \\
\text { Z.Wang }\end{array}$ & $\begin{array}{l}\text { L. Averyanov } 1987 \text { [Cult. } \\
\text { RBGE 19941913] }\end{array}$ & $\mathrm{E}$ & \begin{tabular}{|c|} 
Vietnam, Hong Quang \\
Special Region, Cat \\
Hai
\end{tabular} & FJ501345 & FJ501523 \\
\hline
\end{tabular}

Note: newly generated sequences indicated by an asterisk $\left({ }^{*}\right)$.

\section{Taxonomic treatment}

\section{Chayamaritia vietnamensis F.Wen, T.V.Do, Z.B.Xin \& S.Maciej, sp. nov.} urn:Isid:ipni.org:names:77217099-1

Figs 2, 3C

Diagnosis. The new species can be easily distinguished from the known Chayamaritia species by its peltate leaf blades. Besides, it differs from $C$. banksiae by its leaf blades apex rounded and margin entire (vs. apex shortly acuminate and margin minutely dentate); bracts 3, apex rounded and margin entire (vs. 2, apex acuminate and margin 


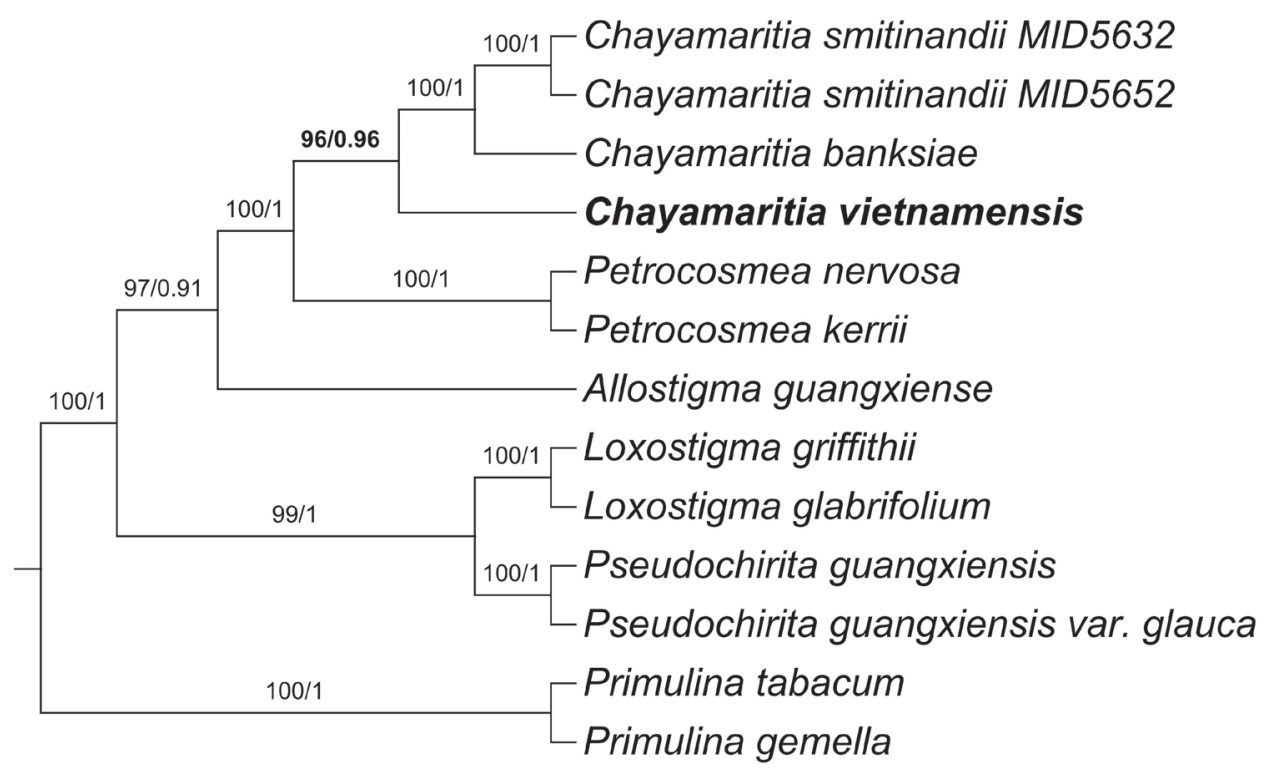

Figure I. Phylogenetic tree of Chayamaritia and related genera generated from the Maximum Likelihood analysis (ML) of the combined dataset (ITS and trnL-F). Numbers on the branches indicate bootstrap values $(\geq 50 \%)$ of the ML and the posterior probability $(\geq 0.5)$ of the BI analyses. Created by Long-Fei Fu.

dentate); calyx lobes inside glabrous and margin entire (vs. inside with white appressed hairs in upper half, margin coarsely dentate); corolla lobes margin entire (vs. margin being minutely dentate); lateral staminodes $2.5-4 \mathrm{~mm}$ long (vs. $5.5-11 \mathrm{~mm}$ long). It also differs from $C$. smitinandii by its leaf blades apex rounded and margin entire (vs. apex acuminate and margin minutely dentate); bracts 3 , ovate narrow and apex rounded (vs. 2, narrowly elliptic to lanceolate, somewhat falcate, apex acuminate); calyx lobes inside glabrous and margin entire (vs. inside densely pubescent, margin slightly toothed or appearing as large sessile glands on margin).

Type. Vietnam. Son La Province: Moc Chau District, Xuan Nha Nature Reserve, $20^{\circ} 43^{\prime} \mathrm{N}, 104^{\circ} 40^{\prime} \mathrm{E}$, elev. ca. $850 \mathrm{~m}, 31$ October 2019, F. Wen, T.V. Do, Z.B. Xin \& S. Maciejewski, VMN-CN1214 (Holotype: VNMN!; Isotypes: IBK!, VNMN!).

Description. Herbs perennial, rhizomatous prostrate thickened stem. Leaves basal, alternately arranged, numerous; petioles cylindrical, $10-25 \mathrm{~cm}$ long, $6-8 \mathrm{~mm}$ in diameter, densely covered with short white appressed hairs; leaf blade ovate to elliptic, peltate, $12-20 \times 10-15 \mathrm{~cm}, 1.2-1.3$ times as long as wide, both surfaces densely covered with short white appressed hairs, base rounded, apex rounded, margin entire; lateral veins 6-9 on each side of the mid-rib, impressed on the adaxial surface, prominent on the abaxial surface. Inflorescences cymose, all axes and bracts pale green with red appressed hairs; cymes 4-6, axillary, 1-3-branched, 2-12-flowered; peduncle 15-25 cm long, 4-6 $\mathrm{mm}$ in diameter, scattered villous; bracts 3, narrow ovate, $1.3-1.6 \mathrm{~cm}$ long, 5-6 mm wide, adaxially sparsely villous, abaxially densely villous, margin entire, apex rounded; 

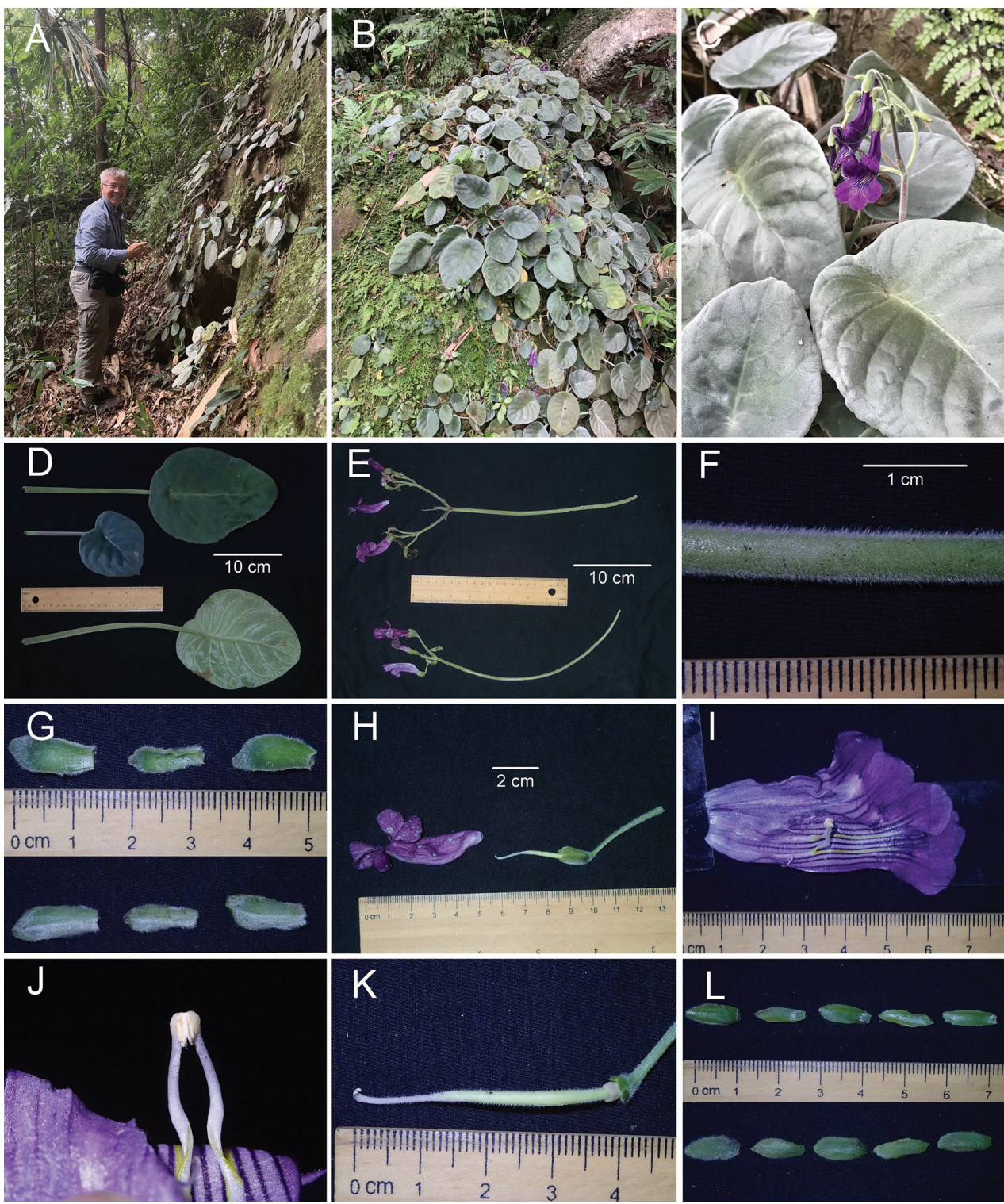

Figure 2. Chayamaritia vietnamensis F.Wen, T.V.Do, Z.B.Xin \& S.Maciej A, B habitat $\mathbf{C}$ habit D adaxial (top) and abaxial (bottom) surface of leaf blade $\mathbf{E}$ cymes $\mathbf{F}$ peduncle $\mathbf{G}$ adaxial (top) and abaxial (bottom) surface of bracts $\mathbf{H}$ pistil, calyx and lateral view of corolla $\mathbf{I}$ opened corolla with stamens and staminodes $\mathbf{J}$ stamens with cohering anthers $\mathbf{K}$ pistil $\mathbf{L}$ adaxial (top) and abaxial (bottom) surface of calyx lobes. Photos by Fang Wen, arranged by Zi-Bing Xin.

pedicel $2.5-3.5 \mathrm{~cm}$ long, $1.5-2 \mathrm{~mm}$ in diameter, spreading puberulent. Calyx 5-parted nearly to the base, strongly imbricate; lobes ovate, ca. $1.3 \mathrm{~cm}$ long, ca. $6 \mathrm{~mm}$ wide, appressed villous outside, glabrous inside, margin entire, apex acuminate. Corolla 5.5$6.5 \mathrm{~cm}$ long, dark purple throughout outside, white to pale purple with two parallel 

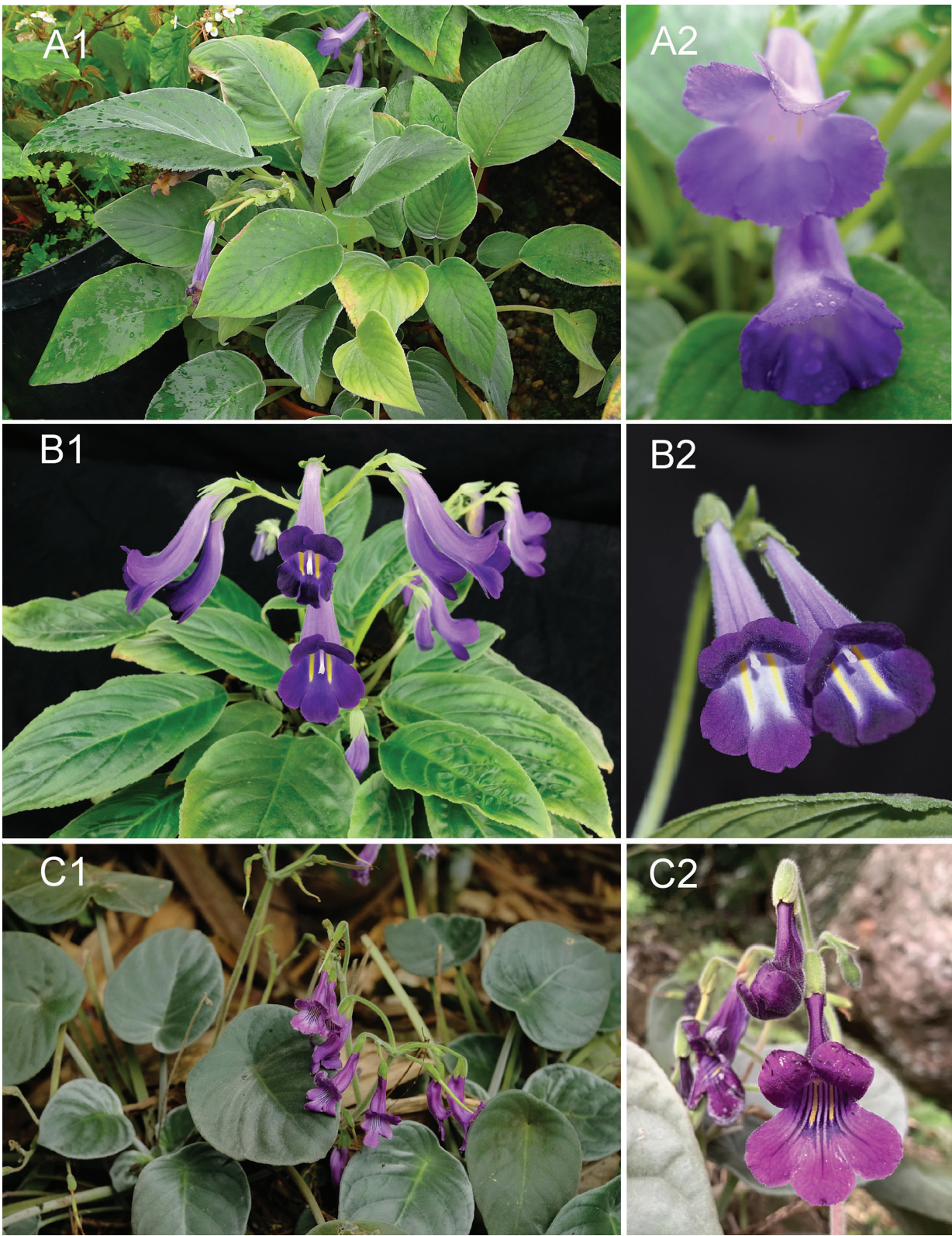

Figure 3. Three species of Chayamaritia A C. banksiae D.J.Middleton B C. smitinandii (B.L.Burtt) D.J.Middleton C C. vietnamensis F.Wen, T.V.Do, Z.B.Xin \& S.Maciej. Photos by Fang Wen, arranged by Zi-Bing Xin.

yellow lines ventrally inside, lobes purple outside and inside, paler at base; tube 3.5-4 $\mathrm{cm}$ long, $1-1.2 \mathrm{~cm}$ in diameter at the mouth, $6-8 \mathrm{~mm}$ in diameter at the base; limb distinctly 2-lipped, adaxial lip 2-parted to over middle, lobes ca. $1 \times 1 \mathrm{~cm}$, orbicular; abaxial lip 3-parted to near the middle, lobes 1.3-1.5 × ca. $1 \mathrm{~cm}$, oblong. Stamens 2, 
adnate to ca. $2.2 \mathrm{~cm}$ above the base of the corolla tube; filaments $1-1.2 \mathrm{~cm}$ long, white, sparsely pubescent, strongly geniculate at ca. $5 \mathrm{~mm}$ above the filament base, anthers ca. $2 \mathrm{~mm}$ long, sparsely pubescent. Staminodes 3 , lateral ones $2.5-4 \mathrm{~mm}$ long, white, glabrous, adnate to $1.8 \mathrm{~cm}$ above the base of the corolla tube, the middle one ca. $0.5-1$ $\mathrm{mm}$ long, adnate to $1.2 \mathrm{~cm}$ above the base of the corolla tube. Disc orbicular, ca. $3 \mathrm{~mm}$ in height, 5-crenate at the margin, glabrous. Pistil $4-4.5 \mathrm{~cm}$ long, ovary $2.5-2.8 \mathrm{~cm}$ long, $2-2.5 \mathrm{~mm}$ in diameter, mixed pubescent and glandular-pubescent; style 1-1.2 $\mathrm{mm}$ long, ca. $0.6 \mathrm{~mm}$ in diameter, mixed pubescent and glandular-pubescent; stigma only of lower lobe, bifid with blunt lobes, lobe ca. $3 \mathrm{~mm}$ long, ca. $0.5 \mathrm{~mm}$ in diameter. Capsules straight, $5.5-6.5 \mathrm{~cm}$ long, ca. $3.5-4 \mathrm{~mm}$ in diameter.

Phenology. Flowering occurs from October to December and fruiting from November to January.

Etymology. The specific epithet "vietnamensis" is derived from Vietnam, which holds the first discovered and only known location for the species.

Distribution and habitat. Chayamaritia vietnamensis is hitherto only known from the type locality, Xuan Nha Nature Reserve, Moc Chau District, Son La Province, northern Vietnam. It grows on rock surfaces surrounded by limestone areas in a subtropical evergreen seasonal rain forest.

Conservation status. Chayamaritia vietnamensis is known from two small-sized populations in the Xuan Nha Nature Reserve's buffer zone. The EOO and AOO of the new species are about $6.15 \mathrm{~km}^{2}$ and $2.2 \mathrm{~km}^{2}$, respectively. Furthermore, the natural habitat is mostly disturbed by local farmers who impose intense pressure on the remaining primary forest patches, by converting the natural habitat of the species into cornfields. Thus, following the IUCN Red List Categories and Criteria (IUCN 2019), it is provisionally assessed as endangered (EN B1ab(iii), B2ab(iii))

\section{Identification key for the three known Chayamaritia species (Fig. 3)}

1 Leaf blade peltate, apex rounded, margin entire

C. vietnamensis

- $\quad$ Leaf blade not peltate, apex acuminate, margin minutely dentate............... 2

2 Calyx lobes 7-15 mm wide, corolla tube white ventrally........... C. banksiae

- $\quad$ Calyx lobes $0.9-4.2 \mathrm{~mm}$ wide, corolla tube purple ventrally .... C. smitinandii

\section{Discussion}

From the viewpoint of morphology, the newly-described species should be treated as a species of Chayamaritia, because it exhibits a suite of morphological characters that are diagnostic to the genus and should not be established as a distinct genus. It has a thickened rhizomatous prostrate stem, alternately arranged leaves and imbricate sepals (Middleton et al. 2015). The current molecular work also confirmed that the new species is sister to a clade comprising the two known Chayamaritia species (C. banksiae and C. smitinandii). A detailed morphological comparison of the new species with its 
Table 2. Morphological comparison of Chayamaritia vietnamensis and its two relatives.

\begin{tabular}{|c|c|c|c|}
\hline Characters & C. vietnamensis & C. banksiae & C. smitinandii \\
\hline Leaf blade & $\begin{array}{c}\begin{array}{c}\text { peltate, } 1.2-1.3 \text { times as long as } \\
\text { wide, apex rounded, margin } \\
\text { entire }\end{array} \\
\end{array}$ & $\begin{array}{c}\text { palaceous, } 1.5-1.9 \text { times as long as wide, } \\
\text { apex shortly acuminate, margin } \\
\text { minutely dentate }\end{array}$ & $\begin{array}{l}\text { palaceous, } 1.8-5.6 \text { times as long as wide, } \\
\text { apex acuminate, margin minutely dentate }\end{array}$ \\
\hline Bracts & $\begin{array}{l}\text { 3, narrow ovate, } 5-6 \mathrm{~mm} \text { wide, } \\
\text { apex rounded, margin entire }\end{array}$ & $\begin{array}{c}\text { 2, ovate, } 19 \mathrm{~mm} \text { wide, apex acuminate, } \\
\text { margin dentate }\end{array}$ & $\begin{array}{l}\text { 2, narrowly elliptic to lanceolate, somewhat } \\
\text { falcate, } 1.8-8 \mathrm{~mm} \text { wide, apex acuminate, } \\
\text { margin entire }\end{array}$ \\
\hline Pedicels & $25-35 \mathrm{~mm}$ long & $12-15 \mathrm{~mm}$ long & $6.5-11 \mathrm{~mm}$ long \\
\hline Calyx lobes & $\begin{array}{l}\text { 4-6 mm wide, inside glabrous, } \\
\text { margin entire }\end{array}$ & $\begin{array}{c}7-15 \mathrm{~mm} \text { wide, inside with white } \\
\text { appressed hairs in the upper half, margin } \\
\text { coarsely dentate }\end{array}$ & $\begin{array}{c}\text { 0.9-4.2 mm wide, inside densely } \\
\text { pubescent, margin slightly toothed or } \\
\text { appearing as large sessile glands on margin }\end{array}$ \\
\hline Corolla & $\begin{array}{c}\text { outside dark purple throughout, } \\
\text { lobes margin entire }\end{array}$ & $\begin{array}{l}\text { outside white ventrally, lobes being } \\
\text { minutely dentate along the margin }\end{array}$ & $\begin{array}{l}\text { outside deep purple throughout, lobes } \\
\text { margin entire }\end{array}$ \\
\hline \begin{tabular}{l|l} 
Lateral \\
staminodes
\end{tabular} & $2.5-4 \mathrm{~mm}$ long & $5.5-11 \mathrm{~mm}$ long & $4-5 \mathrm{~mm}$ long \\
\hline Disc & ca. $3 \mathrm{~mm}$ high & ca. $1.5 \mathrm{~mm}$ high & $0.9-1.4 \mathrm{~mm}$ high \\
\hline
\end{tabular}

two relatives is summarised in Table 2. This new species is the first Chayamaritia species reported from Vietnam. In order to facilitate identification, we also provide an identification key to all known Chayamaritia species.

\section{Conclusion}

In the present study, we discovered and described a new species of Chayamaritia from Vietnam, based on both morphological and molecular evidence. This newly-described species further suggests floristic similarities amongst countries of the Indochinese Peninsula. Our new finding provides an essential addition to the ongoing project of 'Flora of Vietnam' and 'Flora of Cambodia, Laos and Vietnam'.

\section{Acknowledgements}

We want to thank the staff from Xuan Nha Nature Reserve for guiding our investigation and collecting the specimens. We also want to thank Michael LoFurno, Adjunct Professor, Temple University, Philadelphia, USA, for his editorial assistance. This study was financially supported by the Vietnam National Foundation for Science and Technology Development (NAFOSTED) (106.03-2019.308), the Foundation of Guangxi Key Laboratory of Plant Conservation and Restoration Ecology in Karst Terrain (19-050-6; 19-185-7), the National Natural Science Foundation (31860047), Guilin Science and Technology Foundation (20180107-6), the Key Science and Technology Research and Development Project of Guangxi (Guike AD20159091), Guangxi Natural Science Foundation (2020GXNSFBA297049), Basal Research Fund of GXIB (Guizhiye20009) and the $21^{\text {st }}$ Talent project of "TenHundred-Thousand" in Guangxi. 


\section{References}

Burtt BL (2001) Thailand-annotated checklist of Gesneriaceae. Thai Forest Bulletin (Botany) 29: 81-109.

Chase MW, Hills H (1991) Silica gel: An ideal material for field preservation of leaf samples for DNA studies. Taxon 40(2): 215-220. https://doi.org/10.2307/1222975

Doyle JJ, Doyle JL (1987) A rapid DNA isolation procedure for small quantities of fresh leaf tissue. Phytochemical Bulletin 19: 11-15.

Harris JG, Harris MW (2001) Plant Identification Terminology: An Illustrated Glossary (2 $2^{\text {nd }}$ ed.). Spring Lake Publishing, Payson, 216 pp.

IUCN (2019) Guidelines for Using the IUCN Red List Categories and Criteria. Version 14. Prepared by the Standards and Petitions Subcommittee of the IUCN Species Survival Commission. http://cmsdocs.s3.amazonaws.com/RedListGuidelines.pdf

Katoh K, Standley DM (2013) MAFFT multiple sequence alignment software version 7: Improvements in performance and usability. Molecular Biology and Evolution 30(4): 772780. https://doi.org/10.1093/molbev/mst010

Middleton DJ, Nishii K, Puglisi C, Forrest LL, Möller M (2015) Chayamaritia (Gesneriaceae: Didymocarpoideae), a new genus from southeast Asia. Plant Systematics and Evolution 301(7): 1947-1966. https://doi.org/10.1007/s00606-015-1213-2

Nishii K, Hughes M, Briggs M, Haston E, Christie F, DeVilliers JM, Hanekom T, Roos GW, Bellstedt UD, Möller M (2015) Streptocarpus redefined to include all Afro-Malagasy Gesneriaceae: Molecular phylogenies prove congruent with geography and cytology and uncovers remarkable morphological homoplasies. Taxon 64: 1243-1274. https://doi. org/10.12705/646.8

Posada D, Buckley T (2004) Model selection and model averaging in phylogenetics: Advantages of Akaike Information Criterion and Bayesian approaches over likelihood ratio tests. Systematic Biology 53(5): 793-808. https://doi.org/10.1080/10635150490522304

Ronquist F, Teslenko M, Van Der Mark P, Ayres DL, Darling A, Höhna S, Larget B, Liu L, Suchard MA, Huelsenbeck JP (2012) MrBayes 3.2: Efficient Bayesian phylogenetic inference and model choice across a large model space. Systematic Biology 61(3): 539-542. https://doi.org/10.1093/sysbio/sys029

Silvestro D, Michalak I (2012) raxmlGUI: A graphical front-end for RAxML. Organisms, Diversity \& Evolution 12(4): 335-337. https://doi.org/10.1007/s13127-011-0056-0

Thiers B (2019) Index Herbariorum: a global directory of public herbaria and associated staff. New York Botanical Garden's Virtual Herbarium. http://sweetgum.nybg.org/ih [Accessed 10 August 2020]

Wang WT, Pan KY, Li ZY, Weitzman AL, Skog LE (1998) Gesneriaceae. In: Wu ZY, Raven PH (Eds) Flora of China (Vol. 18). Science Press, Beijing \& Missouri Bot Garden, St. Louis.

Weber A, Middleton DJ, Forrest A, Kiew R, Lim CL, Rafidah AR, Sontag S, Triboun P, Wei YG, Yao TL, Möller M (2011) Molecular systematics and remodelling of Chirita and associated genera (Gesneriaceae). Taxon 60(3): 767-790. https://doi.org/10.1002/tax.603012

Wei YG, Wen F, Zhao B, He SZ (2013) Anna rubidiflora (Gesneriaceae), a new species from Guizhou, the southern part of China. Plant Ecology and Evolution 146(2): 203-211. https://doi.org/10.5091/plecevo.2013.731 


\section{Supplementary material I}

\section{Log file}

Authors: Zi-Bing Xin, Long-Fei Fu, Stephen Maciejewski, Zhang-Jie Huang, Truong Van Do, Fang Wen

Data type: phylogenetic

Copyright notice: This dataset is made available under the Open Database License (http://opendatacommons.org/licenses/odbl/1.0/). The Open Database License $(\mathrm{ODbL})$ is a license agreement intended to allow users to freely share, modify, and use this Dataset while maintaining this same freedom for others, provided that the original source and author(s) are credited.

Link: https://doi.org/10.3897/phytokeys.177.63401.suppl1 